\title{
For ourselves and for each other - Politics of embodied religious belonging in the novel We Sinners
}

\author{
SANDRA WALLENIUS-KORKALO \\ SANNA VALKONEN \\ University of Lapland
}

\begin{abstract}
This article analyses religious belonging in a Christian revivalist community through a reading of Hanna Pylväinen's novel We Sinners, a fictive history of a Laestadian family in the modern American Midwest. Like many conservative religious groups today, Laestadianism is increasingly affected by secular society's norms and practices. We claim that the study of everyday religious belonging is essential in order to make sense of the power relations, structures, and dynamics of change within religious groups. The article approaches belonging as a thoroughly embodied state, taking the view that certain kinds of corporeality threaten the cohesion of religious communities while others strengthen it. The politics of belonging in the novel - the practices of inclusion and exclusion - are constructed in, on, and through the regulation of individual bodies. Control over clothing, behaviour, sexuality, movement, and being-in-common produces and governs embodied Laestadian subjectivity, as well as the ways in which belonging is shared.
\end{abstract}

Keywords: politics of belonging, embodiment, Laestadianism, literary fiction

This article analyses the complexity of embodied practices of belonging and not belonging in a Christian revivalist community, Laestadianism. ${ }^{1}$ Like many conservative religious groups today, Laestadianism is under pressure to change as it is increasingly affected by secular society's norms and practices (cf. e.g. Aune 2011; McGuire 1997). The movement's power structures

1 Laestadianism is a conservative Lutheran revival movement founded on the spiritual work of a Swedish-Sámi scientist and priest, Lars Levi Laestadius (1800-61). Laestadians today are characterised by their large families, conservative values, and exclusive social identity. There are an estimated 200,000 Laestadians worldwide, most of them living in Finland, Sweden, Norway, and North America (see e.g. Lohi 1997; Talonen 2001). 
are being debated within the community, as well as in public forums, the media, the internet, academic research, literature, and film (see e.g. Hurtig 2013, 33-42; Nykänen 2012, 220-59). These discussions raise the many challenges that the community faces as it tries to maintain its traditional way of life, internal cohesion, and membership. The debates attest to the community's practices of inclusion and exclusion, and ponder questions of belonging and identification. In this article we approach the problematic of belonging to a religious group through a reading of Hanna Pylväinen's novel We Sinners, a fictive history of a Laestadian family living in the modern-day American Midwest. The movement's debates on belonging are made tangible through the lens of the book's narrative and the experiences related by the characters.

Nira Yuval-Davis $(2011,2,113-45)$ identifies religion as an impetus for one of the major political projects of belonging in the contemporary world. Religions are forces of cohesion and conflict, constructing, as well as dividing, collectives and groups (Berger 1990, 100-1). Religions are politically significant entities in societies, nations, and world politics; social-scientific and political research on religion thus often focuses on socio-politically meaningful, macro level issues (e.g. Yip \& Nynäs 2012, 8). This article situates its analysis on the micro level, and approaches belonging as a thoroughly embodied matter. We claim that the study of the representations of the micro level of lived religious belonging is essential if we are to make sense of the power relations, structures, and dynamics of change within religious groups, as well as between these groups and society at large.

Religious norms have a fundamental influence on the embodied subjectivity and everyday life of people in religious communities. Everyday life is lived under different structural constraints, which are simultaneously negotiated, reinterpreted, and challenged; at the same time the structures of everyday life affect wider political projects of identification (e.g. Pink 2012; Yip \& Nynäs 2012, 8). This interplay of power structures in everyday life is situated fundamentally in bodies. As Meredith McGuire $(2008,173)$ argues: 'Body postures, gestures, use of space and time serve, simultaneously, to express metaphorically and actually perform political arrangements - power relationships.'

This article argues that belonging to the Laestadian movement is constructed in, and regulated by, bodily practices. The body underpins belonging in the world spatially and physically, as well as mentally and emotionally. Bodily, sensory, and affective engagement is foundational to human orientation (Riis \& Woodhead 2010, 207); belonging is about identification as well as emotional and corporeal attachment. People can belong in 
many ways and to many groups, with some forms of belonging being more important than others in terms of self- and group identification: belonging bears on the question of what makes us who we are (e.g. Yuval-Davis 2011). In Laestadianism belonging consists of belonging not only to a social community, but to the Kingdom of God. It is regulated by both religious and social norms. As Vikki Bell (1999, 1; see also Probyn 1996) points out, there is 'yearning implied' in the concept of belonging: it is 'not just be-ing but longing'. People want and need to belong, and in Laestadianism this longing is directed not only towards the temporal community of believers, but also the eternal Kingdom of God.

However, belonging is never a fixed entity; it is a constantly fluctuating project. In everyday life belonging is often naturalised as part of mundane practices; only when it is threatened in some way is it articulated (YuvalDavis 2011, 10-2). Bodily acts can reinforce and naturalise belonging. Such acts can also problematize, contest - and therefore politicise - the norms and boundaries of a religious community, and hence belonging to it. Using Yuval-Davis's (2011) concept, we call this process 'the politics of belonging', the separation of people into ' $\mathrm{us}^{\prime}$ and 'them', the struggle to maintain boundaries, and determine who a member is and what being a member of the community of belonging entails.

In this article we look at the points at which belonging is constructed and challenged in light of the fact that certain kinds of corporeality threaten the cohesion of a religious community, while others strengthen it. We claim that in these situations embodied belonging becomes politicised. We ask the following questions: (1) Through what kinds of bodily practices does belonging become affirmed or politicised? (2) What are the consequences of the politicisation of belonging for the individual and the community? and (3) What does the novel tell us about the dynamics of inclusions and exclusions in religious communities?

While the perspective of the controlled body is a focal one, research needs to be sensitive to the lived and experienced body, as well as to recognising the creative capability of bodies, that is, their potential for changing their social environment (Schilling 2012, 241-56). We address these questions in a threefold inquiry into the novel: first, we analyse the norms and control of the religious body in its physical appearance and movement; second, we look at the corporeal choreographies and limits of lived bodies; and finally, we examine the embodied practices and experiences of regulative sin and grace. At the end of the article we return to the wider question of belonging in religious communities and to the role fiction can play in its study. 


\section{Laestadianism and literary fiction}

Laestadianism originated around the mid-1800s in the northern parts of Finland and Sweden, from where it rapidly spread through Finland, northern Scandinavia, and elsewhere (e.g. Lohi 1997). Finnish immigrants brought the movement to North America as early as the 1860s (Raittila 1982, 11-2). The history of the movement is characterised by successful expansion, but also by several disputes and divisions. The main branch of Laestadianism, today with more than 100,000 followers, is Conservative Laestadianism (Talonen 2001, 11; Hepokoski 2002). The Laestadian Lutheran Church (LLC), which forms the setting of the novel We Sinners and the writer's background, is a sister organisation of Finnish Conservative Laestadianism. The LLC was established in 1973, and today it has about thirty member congregations in the United States and Canada, with the highest concentrations in Minnesota, Washington, Arizona, Michigan, and Saskatchewan (see LLC 2016). The church arranges and conducts services, teaches children and youth, publishes literature and magazines, and works with its sister organisations around the world (ibid.).

Laestadianism is usually a family tradition: the movement grows mainly from within, and socialisation to the movement happens as a child through upbringing (e.g. Hurtig 2013, 42-9; Kutuniva 2007, 19; Snellman 2011). What distinguishes Laestadians from most of Western secular society is that they live by strict moral codes and practices and standards of religiosity. They do not generally, for example, approve of premarital sex, allow contraception, use alcohol or make-up, dance, or watch television. Many Laestadians today do, however, use the internet. Laestadians participate actively in their congregation and emphasise strong personal religious conviction. Conservative Laestadians also believe that their church represents Christianity in its purest form, and that outside the church there is no salvation (see e.g. Hurtig 2013, 24-49; Linjakumpu 2012; Nykänen 2012). The LLC shares the main characteristics and norms of the latter concerning, for example, the position of women, birth control, alcohol, and dancing; but it is an even more close-knit and introverted community than its Finnish counterpart (Hepokoski 2002; Lohi 1997; Talonen 2001; see also LLC 2016).

In recent years, especially in Finland, the Laestadian movement has been increasingly discussed in the media, research, and literature. ${ }^{2}$ The movement received wider international attention when We Sinners, a critically acclaimed debut novel by Hanna Pylväinen, a young American writer, was

2 The main debates revolve around the position of women in Laestadianism, reported cases of child abuse, as well as accusations of spiritual violence and the community's relationship with its past (see e.g. Hintsala 2012; Hurtig 2013; Linjakumpu 2012; Rauhala 2013). 
published in August 2012. The novel, one of the very few works of literary fiction in English featuring Laestadianism, quickly gained attention from reviewers and readers. ${ }^{3}$ The work follows the Rovaniemis, a family of eleven with Finnish origins, who belong to the Laestadian Lutheran Church in the modern day American Midwest. In each chapter the story is told from the perspective of a different family member, portraying the Rovaniemis' everyday life as they struggle with their faith. ${ }^{4}$

Hanna Pylväinen is a fourth-generation Finnish immigrant and her family is Laestadian, although she herself has left the church. The novel is not an autobiography, but the author draws heavily on her personal background and experiences. ${ }^{5}$ As such, the writer has an intimate relationship with the novel's theme. She is both an outsider and an insider where the movement is concerned. Pylväinen's background gives her profound knowledge of the everyday practices and norms of Laestadianism. However, having left Laestadianism, her perspective may be critical towards certain aspects of the community. It must also be recognised that a novel is constrained by the demands of literary genre, and, as a narrator, Pylväinen can choose to emphasise themes that she finds important for a discussion of Laestadianism. A single book cannot present a general view of Laestadianism, but the way it ties into other contemporary representations and research suggests that it does capture a wider perception (cf. Sjö \& Häger 2015, 39).

In the present case literary fiction offers an intriguing insight into the different aspects of individuals' struggles with their faith and life choices in Laestadianism. We claim that the book and its story are a part of the discussion about belonging in Laestadianism. Given this focus, the novel addresses various sensitivities and potential blind spots in the practices and consequences of inclusion and exclusion. As fiction, the work may also reveal themes that are otherwise difficult to broach. In the hegemonic discourse of the Laestadian movement these include sexuality and violence (Hintsala 2012). Through a literary genre the description of bodies, as well as of bodily experiences and practices, becomes approachable and tangible.

3 Pylväinen received the 2012 Whiting Writers' Award for the book, and We Sinners was also listed among Amazon's Best Books of the Month when published.

4 The last chapter of We Sinners is not included in this case study, as it is a separate story from the rest of the book, narrated by a fictional Sámi woman living in Finnish and Norwegian Lapland in 1874.

5 For more about Hanna Pylväinen, see e.g. interview on NPR books <http://www.npr. org/2012/08/26/159928880/faith-family-and-forgiveness-in-we-sinners>, accessed 2 February 2016; see also Pylväinen's website <http://www.hannapylvainen.com/>, accessed 2 February 2016. 
As Sarah Pink $(2012,44)$ notes, 'there is a well-established tradition of the study of everyday life through the analysis of its representations' especially in cultural studies. In the following analysis we approach the novel as a source of knowledge about possible Laestadianism. We do not claim that the novel reveals Laestadian empirical reality as such. The novel is a representation, a story written by a person with a certain background and perspective. However, and as such, we see it as a valuable insight into everyday Laestadian life which could be so (see also Pink 2012, 45). Our reading of the novel searches for contingencies and ruptures, structures and norms that appear within the novel's narrative. We trace how the novel portrays the practices of inclusion and exclusion, and its embodiment in Laestadianism.

Literary fiction may acquire different meanings in altered contexts. As Rita Felski (2008, 9-10; see also Rusu 2014) maintains, literary texts are 'formative in their own right': that is, they are representations which summon up new ways of seeing. It is important to study and dissect such fictional material since, in addition to being emphatically engaging and medial in nature (or perhaps because it is), fiction has the power to shape individual and shared cultural ideas (Erll 2008, 389, 396-7). We Sinners has a potentially large readership: people unfamiliar with Laestadianism are also likely to read the novel. It mediates Laestadianism to its readers and perhaps others too. We Sinners thus contributes to the public discussion about Laestadianism and is involved in the construction of the image of Laestadians. Furthermore, while the novel discusses themes that are particular to Laestadianism, it also evokes questions that might apply to religious communities in general.

Recent studies of Laestadianism have examined the community from the perspectives of Foucaultian conceptions of power, focusing on various inherent power structures and mechanisms (e.g. Linjakumpu 2012; Nykänen 2012; 2013), while gender perspectives have highlighted the gendered nature of the community's structuring (e.g. Hintsala 2012; Nissilä 2013; Pelkonen 2013; Valkonen 2013; see also Ahonen \& Vuola 2015). The appearance of Laestadianism in fiction, especially in film, has also been discussed (e.g. Sjö \& Häger 2015; Wallenius-Korkalo 2013). In the following analysis of religious belonging in the novel we claim that the power of individual bodies and, in particular, power over them are central in the making of the Laestadian community. 


\section{Boundaries dressed up - Physical appearance and movement as bodily expressions of (not) belonging}

Religious groups exert control over the physical bodies of their members. Being Laestadian and belonging to the community are expressed bodily in various ways. One of the most evident practices constructing and reinforcing a person's belonging to the Laestadian community, but that can also contest it, is outward appearance. Applied directly to the body, concretely worn and put on, dress is one of the most effective symbols of social control (Arthur 2000, 2). Dress, including clothing and accessories, as well as the use of cosmetics and other means of changing one's appearance, is crucial in social interaction: it is an expression of identity and a means of non-verbal communication. Through dress we locate ourselves and others in our social environments (Arthur 1999, 3).

Laestadianism adheres to a strong ideal of both internal and external modesty. In Laestadianism bodily adornment is frowned upon and deemed sinful. Prohibiting the use of jewellery, make-up, and revealing clothing constructs and reinforces the boundary between Laestadians and others (Kutuniva 2007, 21). Dress constitutes a representation of visual cohesion, communicating the religious group's boundaries (Utriainen 2006, 46; Arthur 1999, 3-4). However, Laestadians today lack any easily distinguishable dress code. Negotiating sameness and difference in what Laestadians wear becomes, therefore, an issue of how belonging - and not belonging - are expressed, not only to the other members of the movement, but to the outside world as well.

In the novel Laestadians show their belonging to the community through their choice of dress, but at the same time try to fit in with the rest of the world. The teenagers in particular dress to emphasise solidarity with or distinction from their peers. Nels, the eldest son of the Rovaniemi family, makes observations about the dress style of a Laestadian girl, Tricia, who, compared to the people around them, looks 'both the same and apart':

Tricia smiled without showing her teeth [...] slightly infantile-her T-shirt was plain and white-and average in every way, in what she wore, in how she did her hair. It occurred to him that almost everyone in the church dressed this way, as if dressing like a modest version of everyone else would keep them both the same and apart. (Pylväinen 2012, 76.)

The Laestadians' dress style is similar enough to others' that they do not stand out immediately: while it reflects what others wear, it is more modest, a plainer version of popular fashion, effectively distinguishing them as a 
group of their own. However, the Laestadians in the novel are not indifferent about clothes. Sibling rivalry and jealousy are common when someone gets a new pair of jeans; and the Rovaniemi girls dress up and try to impress the opposite sex, even though they are not supposed to: 'The Karvonen boys were in town and Tiina didn't mean to dress carefully, but she did. All of her sisters did, even Brita, who was pregnant again.' (Pylväinen 2012, 86.)

Even after leaving the Laestadian church, as some of the characters in the novel do, the effect of the Laestadian 'dress code' does not disappear. Maintaining appearances is a matter of maintaining family and community ties. After her separation from the church, one of the Rovaniemi daughters, Julia, works in a lingerie shop, a secret kept from her family. As she returns to visit her parents, she tries to fit in by putting her body back into the mould of a Laestadian woman and daughter.

[S]he had tried to seem like an approvable daughter [...] she took off her nail polish and makeup when she went home, and kept her shirts long and loose. She wore bras that shrank her chest. [...]

She wanted to prove that she could leave the church and not become a disaster. (Pylväinen 2012, 123.)

The novel vividly depicts how, when Julia is back in the community people study her, looking for signs of difference now that she is no longer a member of the church. Julia wants, or feels obliged, to show that she can still belong to an extent, that she is not a 'disaster'. She uses dress to play a role, to look approvable. Belonging in the novel seems to imply a need to look the part. To belong in Laestadianism, women at least are required to a certain extent to look the same. Likewise, one is expected to look different if one does not belong. In dressing, people can cover, frame, correct, and change their bodily identity, and attest to their belonging (see Utriainen 2006, 54-5). Dressing is a question of who we are and who we wish to be (Arthur 2000, 2). This seems to underlie Julia's anxiety as she maintains a Laestadian appearance.

Indeed, the norms and practices regulating the social acceptance of bodies in various contexts are often gendered. Religious meanings are attached to gendered bodies and religious practices socialise people into gendered roles (McGuire 2008, 160-1; see also Ahonen \& Vuola 2015). In the Laestadian community the expectations of what acceptable female and male bodies are derive from the prevailing conceptions of masculinity and femininity, and the role of women and men in the community. Gender hierarchy is woven 
deeply into Laestadianism. The gender matrix of Laestadian community has been described as hegemonic masculinity: women's lives and position in the community are strongly regulated by the movement's normative, conservative, and patriarchal doctrines (Hintsala 2012, 29-30; Ihonen 2001).

Use of cosmetics is a clear symbol of not being Laestadian, especially visible on the female body. Applying make-up, be it mascara or nail polish, represents a transformation or signals insurgency, a breaking away from the community. In the novel the daughter Tiina exhibits this when she lies to her family about going to a seminar. Instead, she goes to meet her boyfriend and plans to announce that she is leaving the church: 'She'd painted her fingernails a bright green - tropical tango-and when she walked toward the baggage claim she knew the nails were a puerile rebellion against the church' (Pylväinen 2012, 89).

In the novel belonging to Laestadianism is possible only within quite specific boundaries of dress; transitional forms are hard to find. Although women are not completely bound by their community's dress codes, they are very aware of their existence: when they take liberties with dress, women are balancing the acceptable and unacceptable (e.g. Utriainen 2006, 49). Tiina's behaviour evinces a protest, but she only shows her painted fingernails to her non-Laestadian boyfriend, not to her family. Tiina, with her polished nails, and Julia, who dresses like a Laestadian, are balancing precariously between two worlds, but neither is ready to show the symbols of not belonging to the Laestadian community.

Struggles of belonging are played out not only on the body, but in the movement of the body and bodies. Eeva Puumala (2012) has discussed the political potential of the moving body and bodies: bodies reach, touch, and stretch towards other bodies, constituting a 'corporeal choreography' of being-in-common. Movement can also interrupt, challenge, and resist cohesive or hegemonic being (Puumala et al. 2011, 86-7). Applying the concept of corporeal choreography to Laestadianism allows an examination of the political potential of moving bodies or, in other words, the disruptiveness of certain kinds of moving. For example, dancing is a type of movement in which the Laestadian (body) does not engage; dancing is a sin. Dancing can produce powerful ecstatic experiences and evoke spiritual attentiveness. However, many conservative Christian communities prohibit dancing or limit music and dance to songs and movements considered appropriate by the church (Kraus 2010, 462; McGuire 2007; 195-6).

In the novel Nels experiences dancing in a club for the first time: letting oneself go, surrendering to the rhythm, appears to him to be a trance-like state, comparable to a religious experience. 
He felt $[. .$.$] alive - there was a strange synchronicity to the dancing, like$ everyone raising their hands to give forgiveness in church. There was a contagion to the movement. [...] He felt a hundred old happinesses rise in him as one. How had this desire - to move like an animal, with crude and sudden movements - waited in him so long? (Pylväinen 2012, 72-3.)

Dancing can be seen as sinful in itself or as an occasion for sin (McGuire 2007, 196). The sinfulness of dancing in Laestadianism stems partly from the implied sexual component; dancing allows bodies to be close to each other. Use of alcohol is also often associated with dancing occasions, compounding the sin. Both these elements are present in Nels's experience. Connecting with other bodies brings him feelings of intense happiness. Spontaneous emotional outbursts and losing control of one's body in this manner are not acceptable for a Laestadian. However, losing control in religious trances has been quite common in Laestadianism. Religious sermons often provoked powerful emotional and corporeal reactions: people cried, rejoiced, shouted, jumped, and fainted (Lohi 1997; Hepokoski 2002). Today this practice of liikutus [literally 'being moved'] is frowned upon, perhaps particularly because the body in a trance or ecstasy is unpredictable and powerful, and inescapably beyond the control of the community (cf. Riis \& Woodhead 2010; see also Linjakumpu 2012; Valkonen 2013).

Dancing is an example of a bodily boundary between Laestadianism and the world. Restricting dancing not only restricts the movement of the body, but may also limit social relations between people. In the novel young Brita's religious conviction is discovered when she declines an invitation to a high school dance. After this her crush leaves her and the whole school starts to gossip about the 'weird cult' she is in. Dancing epitomises the line between the acceptable and unacceptable in two ways: for a Laestadian it is unacceptable to dance; for an American high school girl it is unacceptable not to. Brita tries to overcome her disappointment: 'It was okay, she was different. They were different. They were in the world, but not of the world.' (Pylväinen 2012, 6-7.) The novel highlights a conflict of belonging and not belonging in which belonging to one community, Laestadianism, makes it impossible to belong socially to another, a high school. Here, belonging to a Laestadian community is exclusionary belonging. 'Being in the world but not of the world', as Brita puts it.

Dress and outward appearance signal belonging, or not-belonging, to the Laestadian community. Besides drawing boundaries on the body, the struggles of inclusion and exclusion are expressed and experienced in the movement of the body and bodies. Using dress makes it possible to a certain 
extent to balance the norms of the Laestadian community and the expectations of the rest of the world. A distinct line is drawn in the case of dancing, however. Dancing bodies are out of (Laestadian) order. They attest to the bodily foundations and limits of Laestadian subjects, and to how those foundations and limits underpin the construction of the Laestadian community.

\section{Intensive togetherness - Lived belonging and limits of bodies and space}

The everyday life of a Laestadian is imbued with the embodied practices and material consequences of belonging to the Laestadian community. The sense of connection and identification with family and community arises from seemingly unexceptional functions: mundane activities link individuals' materiality as humans and their religiosity (McGuire 2008, 99, 115). Being within oneself and with each other is extensively structured by Laestadianism; belonging is lived in the (Laestadian) body and between bodies. Lived belonging also introduces limits to the body. It is these limits that are inscribed on and lived in the female body.

Marriage and family are (at) the core of the Laestadian community (Nykänen 2012, 107; see also McGuire 1997, 56). ${ }^{6}$ The primary role of women in the community is that of mother. The religiosity of a woman is tightly bound to her role of bringing up new generations and taking care of mundane chores; women have an important role in keeping and continuing Laestadian tradition (Hintsala 2012; Kutuniva 2007, 27-9; see also Aune 2011, 279; Snellman 2011). As birth control is practically prohibited within the movement, the number of children in Laestadian families is noticeably high. Children are seen as God's gifts to their parents; at the same time, repeated childbearing significantly dictates the life choices that Laestadian women can make and, accordingly, the career opportunities available to them.

The Rovaniemi family has nine children, two of whom have not been born at the beginning of the novel. A stretched belly and an infant in her arms are the essentials of a Laestadian mother: religion for a woman is unavoidably embodied. If the lot of a married Laestadian woman is to be constantly pregnant, it is also the lot of Laestadian children to see their mother constantly pregnant and with another baby, as illustrated by young Brita's observations concerning her mother:

6 The LLC (2016) states on their website, in LLC Position Statement: 'God has established marriage and family in His creation work and they are thus defined and governed by the natural law of God's creation (Gen. 2:18, 23, 24). Attempts to redefine marriage and family and to alter or resist their intended purpose thus injure families and society.' 
Her mother was already lying on her side on top of her own [sleeping bag], the baby asleep against her. Brita realized her stomach looked bigger than she remembered, and she wondered if her mother was pregnant again. Probably, she decided. (Pylväinen 2012, 22-3.)

Laestadian girls learn from early childhood to tie their expectations of the future to motherhood (Nissilä 2013, 64; Pelkonen 2013, 183). Brita's life follows the same path as her mother's. She becomes the mother of a big family herself. However, repeated pregnancies are not without risks: the movement's ban on contraception puts women's health and even lives in jeopardy, as Brita experiences. She nearly dies during her seventh $\mathrm{C}$-section, but later recovers and is able to return home. Mervi Kutuniva $(2007,25)$ talks about the fear of death and the doubts Laestadian women may encounter every time they deliver a baby. Brita questions, to her own horror, whether the new baby was worth her almost dying and leaving her other six children without a mother. She feels that she has no strength to carry on; and her beloved piano becomes a symbol and locus of her depression.

She looked up, and she saw the sun running off the top of the piano, and as if still in the morphine world she saw not a piano but a table, herself flat upon its back, wanting to get up and never able, the rest of her life stretching across its planes. Always there would be more to give, and she had nothing left to give at all. (Pylväinen 2012, 151.)

Puumala (2012, 202-14; Puumala et al. 2011, 97-111) has discussed melancholy, silence, and passivity in the body and bodies of asylum-seekers: she claims that numbness can be seen as a way of overcoming or escaping the grip of a power. Laestadianism's demands on women and their bodies, the burden of continuous pregnancies and motherhood - a lifelong requirement for belonging - become too heavy for Brita. She escapes this power structure in numbness, melancholy, depression, and silence. Brita's child asks her to play the piano and, as she obediently presses a key, it makes no sound at all. The soundless piano echoes Brita's silence.

Although, as Puumala observes, the numb and melancholic body cannot always be interpreted as conscious protest, it is a form of survival and, in a sense, silent resistance. Being melancholic and silent shakes the foundations of established ways of being and belonging in Laestadianism, and calls into question the ever-caring and ever-able mother figure. As Puumala et al $(2011,98)$ note, "the "unspeakable" that is incorporated into the body in 
the form of pain and grief, and therefore that which cannot be said takes the form of gesture and silence' (see also Edkins 2003, 206-8). Even passive and silent bodies are not isolated from their surroundings and other people. They call forth being-in-common in their own way, provoking, for example, silent gestures of compassion (Puumala 2012, 202-14; Puumala et al. 2011, $100)$, as in the encounter of Brita and her mother on the home porch: 'She stepped slowly to the front door, hand to sore stomach, her own mother on the porch, her quiet suggesting she was impressed by what her daughter had endured' (Pylväinen 2012, 150).

All children are welcomed in Laestadianism, but some, those born illegitimate, perhaps less so. It is a great shock to the Rovaniemi family when one of the dutiful and 'good' girls, Leena, becomes pregnant as a teenager. Later readers get a glimpse of Leena and her child. She is raising the boy as a single parent, but with the help of her siblings and mother. Leena's child is playing with Brita's boys and the two women's experience of motherhood, however different, connects them. The ties of motherhood bind the Laestadian women and community (see also Kutuniva 2007, 27). Even a single mother, a grave sinner in the eyes of the community, can belong. She can redeem herself and (re)claim her place through her child and through motherhood.

The novel repeatedly returns to the question the Rovaniemis have to face as their family and faith are coming apart: do we live and believe for ourselves or for each other? The religious subjectivity and agency of the Laestadian women in the novel culminates in their taking care of others. This is especially visible in practices and experiences of motherhood - repeated pregnancies, giving birth, and raising children are how Laestadian women live their faith - but also in the women working in and outside of the home in different types of services, education, and nursing. The women who stay in the church also participate in organising religious meetings by doing chores behind the scenes, such as cooking. At home the Rovaniemi daughters try to be helpful by taking care of their siblings and the household; Leena, a school girl, secretly gets up at night to clean so she can surprise her mother with a tidy house. As McGuire $(2008,118)$ has argued, material bodies thus become linked to spirituality, through myriad mundane activities such as preparing food, working, childbirth, and care. The Laestadian community's 'ethics of care' - the ways in which people relate to and care for each other - arise from and materialise in the family. Whom we care for is inevitably a question of belonging too; the practices of care are sites of social connection and acts of building belonging (Yuval-Davis 2011, 175-99). 
The presence of family members and their bodies dominates the experience of living in a Laestadian family. Bodily togetherness reveals the ways and sites of shared belonging, and also the interruptions and limits of being-in-common (see also Puumala et al. 2011, 86-7). Living Laestadianism, engaging in the Laestadian 'corporeal choreography', governs both being in oneself and with each other. A constant lack of sufficient space characterises the everyday life of the Rovaniemis. The children sleep, play, eat, study, do hobbies, and go everywhere together. They are never alone. There are also so many of them that outsiders - and sometimes even their parents - have trouble telling them apart, and the children have to struggle to be recognised as individuals.

In limited space togetherness is given and sharing inescapable. Belonging obscures individual subjects and their desires, their need to be seen and recognised. Nonetheless, intensive togetherness can also offer them the support and cover of other bodies.

\section{Sin and Grace - Embodied Practices and Experiences of (Not) Belonging}

In Laestadianism belonging and not belonging, inclusion and exclusion, are both performed and experienced bodily. This becomes particularly apparent in the interplay of sin and grace, which in the novel strongly structures the Rovaniemi family's life. Even the title of the novel, We Sinners, highlights the centrality of sin. Sin is most explicitly present in questions of sex and sexuality in the novel. As Andrew Yip and Peter Nynäs $(2012,6)$ argue, 'gender and sexuality are not only about personal identity, embodied subjectivities and bodily performances; they are also about social organisations, structures and relationships'. Social groups, not least religious groups, prescribe what is normative in terms of sexuality to establish order within the group (see e.g. Turner 1984). Stephen Hunt and Andrew Yip (2012, 3-4) maintain that all religions try to some extent to structure sexual behaviour through frameworks of divine morality, and that perhaps no other area is subjected to control and restrictions as extensively as sexuality. In Laestadianism sex and sexuality are regulated strictly and anything deviating from the norm is labelled sinful. Sex has a clearly defined place in the movement: it belongs to heterosexual marriage, typically formed inside the church, and its primary function is reproduction (see e.g. Hintsala 2012; Nykänen 2013, 157-8; see also LLC 2016).

The link between sex and sin is apparent in the book, but in the experiences and actions of the characters this interconnectedness is more complex. Sex and sexuality are focal contexts of defining, testing, and contesting the boundaries of belonging, and thus have the potential to politicise it. Many 
characters in the novel act rebelliously towards the rules and norms regulating sex and sexuality. Some of the daughters of the Rovaniemi family have premarital sex in secret, while belonging to a church that strictly forbids it. This is described as nothing out of the ordinary in the novel: Tiina, the second eldest daughter, has a boyfriend outside the church; Leena, the third youngest of the siblings, is suddenly pregnant; and the youngest daughter, Uppu, a model daughter in many ways, has sex in a car with her partner.

Of the nine Rovaniemi siblings, Tiina, Uppu, Julia, and Simon eventually leave the Laestadian movement. For an unmarried woman - or man - leaving the movement means liberation from the bans concerning sex. However, leaving does not free the Rovaniemi siblings from the thought patterns and norms they have learned from childhood. Sex never seems uncomplicated for them, and the women especially are not portrayed as particularly enjoying sex or their sexual freedom.

From the secularist perspective, religion is often seen as representing traditionalism and authoritarianism; it is considered a constraining and a restrictive force, which polices gendered and sexual subjectivities and practices. Yip and Nynäs $(2012,9)$ observe that this viewpoint has been proven, on numerous occasions, to be too limiting and biased, as it fails to capture 'the multi-faceted and nuanced nature of how religion, gender and sexuality are lived in everyday life'. In the novel the sexual agency of religious actors, as well as their creativity and resistance on the personal and social levels, is recognised and present. However, the relationship between religion and sexuality is still fraught with tension and conflict (cf. Yip \& Nynäs 2012, 9-10; see also Hunt \& Yip 2012).

Not all sex and sexuality is judged equally, nor do all forms test the boundaries of the Laestadian community as potently. The novel's most powerful transgression is the homosexuality of Simon, the youngest Rovaniemi son. Gay men do not fit Laestadianism's traditional heteronormative conception of gender roles. Homosexuality is discouraged and homosexual acts forbidden, as they disrupt the gender and sexual order (Hintsala 2012, 29-30; Kejonen \& Hintsala 2013; Yip \& Nynäs 2012, 6; see also Butler 1990). ${ }^{7}$ The mother of the Rovaniemi family, Pirjo, discovers that teenaged Simon is going out with another boy. She is torn by feelings of love and care to-

7 The LLC (2016) website states, in LLC Position Statement, the movement's stance on homosexuality as follows: '(1) The Bible teaches that homosexual behavior is immoral and a sin, (2) arguments based on God's creation and genetics, even if they can be identified, do not justify homosexual relations, and (3) the increase of homosexuality is a sign of broad moral decline in a society.' 
wards her child on the one hand and the strong conviction that he has done something very wrong on the other:

[S]he half wanted to hug him, to carry him as if he were not sixteen but two or three $[\ldots]$ and at the same time she wanted to shake him, to slap him. She felt slapped, she felt rejected, she felt like he had looked at the life she had made for him and he had spit on it. [...]

At church they said that gayness was a trial, like any other trial, any other temptation, and anyway all sin was the same in the eyes of God. But not in the eyes of man - that, that Pirjo had always known. (Pylväinen 2012, 62.)

Simon's homosexuality is a sin that clearly draws a line where being able to belong is concerned. 'What if I don't want to go, what if I want to stay?', Simon asks his mother, and she thinks to herself: 'It is an impossible life.' (Pylväinen 2012, 61) Homosexuality is a sin that distances a person from the church, despite his or her personal depth of conviction or willingness to belong to the community. It is almost as if homosexuality negates belonging.

Laestadians believe that what is forgiven by another Laestadian and the community is also forgiven in the eyes of God (e.g. Nykänen 2013; see also Hepokoski 2002). Thus, the community has the power to determine the gravity of a sin. Crucial to this power is the Laestadian conception and practice of 'binding sins'. A person can be bound to sins: who and what the community deems sinful - what it does not forgive - God will not forgive either. This bond lasts until the sinner repents, and even then the community has the power to determine the manner and adequacy of any repentance (see also Hurtig 2013; Linjakumpu 2012). This practice makes homosexuality particularly tragic in Laestadianism. In the eyes of the community, as the above excerpt indicates, the sin of homosexuality, especially having homosexual relations, is unforgivable (cf. Kejonen \& Hintsala 2013).

Countering this condemnatory power of the community is the potential of grace and forgiveness. Sin and grace are intricately intertwined. ${ }^{8}$ 'Believe all of your sins forgiven in Jesus's name and precious blood' (Pylväinen $2012,44)$, the Laestadians say to each other. It is a repetitive practice in Laestadianism and one of the most important daily religious rituals (Nykänen

8 The LLC (2016) website defines sin as 'one of the principal concepts of the Bible'; 'sin is the falling away of the heart from God', while repentance is 'a change of heart'; 'it includes penitence and distress on account of sin, but at the same time believing the gospel or the absolution of $\sin ^{\prime}$, as 'the essence of the gospel is the forgiveness of sins'. 
2012, 113): when asked, another believer can forgive you your sins and you receive the grace of repentance. Every night the Rovaniemi children ask each other for forgiveness, and in church they raise their hands in front of the congregation to receive absolution.

McGuire (2008, 100-1) describes these kinds of religious ritual as chains of embodied practices with a potential to awaken strong emotions, senses of social connectedness, and religious meanings: through embodied practices rituals produce real effects for the individual and the religious group practising them. To Leena, the Laestadian practice of forgiving sins is a precious one. She sees the positive, even emancipatory, potential of loosing each other's sins in a process that counters the binding of sins.

Most of all Leena loved 'Whatsoever thou shalt bind on earth shall be bound in heaven: and whatsoever thou shalt loose on earth shall be loosed in heaven' - sins being loosed and let go and gone, all of them keepers and loosers of another's sins. (Pylväinen 2012, 44.)

The forgiving of sins, the words and phrases, can be seen as performative speech acts (e.g. Butler 1990) that produce a certain state of affairs: redemption. Performing forgiveness in Laestadianism is a practice which is repeated in church, in every home, and between friends; it validates and reinforces one's identity as a believer and as part of the community (see also Hurtig 2013, 29). Asking for and giving forgiveness is an act which constructs, renews, and actualises belonging. As an emotional experience, the grace received from forgiveness strengthens Laestadian togetherness.

Performative speech acts have the power to forgive sins - and the power to mark one's detachment from Laestadianism. 'Forgiving sins', Tiina tells her boyfriend, is an example of performative speech: what is said is done at the same time. Like the phrase 'leaving the church', he continues (Pylväinen 2012, 91-2). These are performatives of belonging and not-belonging which are not unconnected to or disjointed from bodies; they have bodily consequences. Bodies can also challenge the constitutive power of speech acts. This is illustrated in the novel repeatedly in the various experiences of the Rovaniemi siblings who leave Laestadianism: although they perform the speech act of renouncing their faith and hence stop being Laestadians in the eyes of the community, they still carry Laestadianism within themselves as patterns of thought, emotion, and habit (see also Pelkonen 2013).

When Tiina, some years after leaving the church, is unfaithful to her boyfriend for the first time, she ponders sinning and the possibilities of forgiveness: 
The night she cheated on Matthew she had been an unbeliever for almost two years. When the new man rolled from her [...] she only wanted him to leave $[. .$.

[S]he had the concrete thought that she had become officially a sinner-she was no good in both the church's world and in the world she had chosen; to all eyes she had sinned. [...] It wasn't about the sinning at all, it was what you did about the sinning, and she had no means of forgiveness about her. (Pylväinen 2012, 102-3.)

Tiina feels that she is a sinner, but this feeling is not new to her: she felt like a sinner when she belonged to the church. Even though sin distances the sinner from the community, sinning is actually something shared among Laestadians: it brings them closer together through forgiveness. As Tiina is no longer a part of the community, she is left with sin, but the possibility of forgiveness has been taken from her. In the novel the lack of forgiveness is the most powerful and devastating experience of exclusion.

\section{Conclusions}

In this article we have analysed the practices of inclusion and exclusion in a religious community, Laestadianism, from the perspective of the body and as a question of belonging. As McGuire (1997, 206-9) has observed, particularistic religious groups are highly concerned with following the 'right' faith, and are intolerant of deviance. We have approached the tension between doing right or wrong as the politics of belonging, and used the novel We Sinners as an illustration and materialisation of this struggle.

The novel is a depiction of relationships between individuals and the Laestadian community that poignantly raises questions of belonging and exclusion. Using fiction as research material is, however, not unproblematic. Sofia Sjö and Andreas Häger (2015, 40-1) have especially criticised the depiction of Laestadianism in Scandinavian cinema, maintaining that Laestadianism is represented from a secular point of view: 'Negative stereotypes still prevail, and filmmakers continue to represent those who choose a more traditional religious worldview as Other.' According to Sjö and Häger, Laestadians in these representations are focused on their community and guided by its norms, which is seen as problematic from the prevailing secular perspective, wherein individuals should come first and religious communities should not restrict them (Sjö \& Häger 2015, 38-9). We Sinners is indeed 
a portrayal of individuals' journeys of self-discovery and finding their way, whether in the Laestadian community or out of it. The community is often depicted as controlling, even abusive at times, which may be claimed to be a stereotype, but the novel's characters are not only 'beaten and subjugated' (cf. Sjö \& Häger 2015, 39), but also intricately human in their wants of and needs towards themselves, each other, and the community.

To understand both religion in general, and specific religious groups in particular, fictive material, as one manifestation of representations of religion and religious difference, should be taken seriously in research (see also Sjö \& Häger 2015, 41). Mihai Rusu claims that literary fiction and academic discussion are in a dialectical relationship, interfering with each other in creative ways: 'Just like social sciences, literary fiction strives to make sense of and to give meaning to human experiences', he notes (Rusu 2014, 133-6). Fiction can also inspire a theorising of social reality: literature contains ideas and foreshadowed concepts that can be worked out into further conceptualisations by the social sciences (Rusu 2014, 133, 147-9). In this article we have taken the novel's depictions of everyday life and struggles between individuals, their family, and the Laestadian community, and used them to conceptualise an embodied politics of belonging.

Although many Christian groups, Laestadianism included, are uncomfortable dealing with human embodiment (see McGuire 2008, 102), we claim that the body is inescapable in the analysis of religious practices and the boundary-making they entail. Laestadian bodies are both symbols and concrete locations where the lines between the acceptable and unacceptable are drawn (see also Utriainen 2006). The politics of religious belonging are inseparable from corporeality; belonging is affirmed, negotiated, challenged, and concretely lived in bodies and bodily practices. The body should thus be placed at the core of the theory and analysis of religious belonging.

The 'dirty work of boundary maintenance' (Favell 1999; Yuval-Davis 2011,20 ) in Laestadianism - what is involved in being a member of the community of belonging and who is a member - focuses essentially on the control of bodies. The boundaries of belonging are constructed in and on individual bodies, and through their regulation. Control over clothing, behaviour, sexuality, movement, and being-in-common produces and governs an embodied Laestadian subjectivity, as well as the community's reaction towards its members and the ways in which, and the sites at which, belonging is shared. The question is how and what a suitable body in Laestadianism in particular is, and (also) in conservative religiousness in general: what kind of body can belong? 
In the novel the interplay of the religious inclusions and exclusions of Laestadianism is situated on gendered and sexualised bodies. There are both gender-specific practices of belonging and acts of transgression. The body of a woman materialises the continuity of Laestadianism's social and religious order and is therefore focal in constructing belonging. The female body is sacred as it gives and carries life and affirms belonging through motherhood and care. Bodies are, however, prone to the worldly: sexuality outside the field of reproduction and marriage - male homosexuality in particular - is a transgression against the social and religious order, and as such problematizes and politicises belonging.

A reading of the novel reveals how sin and grace are ever present and at the centre of the struggle for religious belonging. The embodied experience and mechanics of sin may distance the sinner from the community, but sins also connect Laestadians, and through forgiveness, bring them together. Consequently, forgiving affirms belonging; there is belonging in forgiveness. On balance, the politics of belonging in Laestadianism appear perhaps most crucially to be a struggle for the possibility of forgiveness.

Personal belonging is always relative to others and to the community of belonging; (not) belonging bodies are in a constantly changing and potentially political relationship with each other. The struggle of belonging reverts to the fundamental questions the novel's characters have to consider: do we believe for ourselves or for each other; and do we belong for ourselves or for each other? In the fluctuating project of affirming and contesting religious belonging bodies have a key role: docile bodies make the community but, inescapably, bodies also have an inherent transgressive potential.

SANDRA WALLENIUS-KORKALO is Junior Researcher in Political Studies, University of Lapland, Finland. E-mail: sandra.wallenius-korkalo@ulapland.fi

SANNA VALKONEN is Associate Professor of Sámi research, University of Lapland, Finland. E-mail: sanna.valkonen@ulapland.fi 


\section{Bibliography}

\section{Ahonen, Johanna \& Elina Vuola (eds)}

2015 Uskonnon ja sukupuolen risteyksiä. Helsinki: SKS.

\section{Arthur, Linda}

1999 Dress and the Social Control of the Body. - Linda Arthur (ed.), Religion, Dress and the Body, 1-7. Oxford: Berg.

2000 Introduction. - Linda Arthur (ed.), Undressing Religion: Commitment and Conversion from a Cross-Cultural Perspective, 1-6. Oxford: Berg.

Aune, Kristin

2008 Evangelical Christianity and Women's Changing Lives. - European Journal of Women's Studies 15 (3), 277-93.

\section{Bell, Vikki}

1999 Performativity and Belonging: An Introduction. - Vikki Bell (ed.), Performativity \& Belonging, 1-11. London: Sage.

\section{Berger, Peter}

1990 (1969) The Sacred Canopy: Elements of a Sociological Theory of Religion. New York: Anchor Books.

\section{Butler, Judith}

1990 Gender Trouble: Feminism and the Subversion of Identity. London: Routledge.

\section{Edkins, Jenny}

2003 Trauma and the Memory of Politics. Cambridge: Cambridge University Press.

\section{Erll, Astrid}

2008 Literature, Film, and the Mediality of Cultural Memory. - Astrid Erll \& Ansgar Nünning (eds), Media and Cultural Memory: Cultural Memory Studies: An International and Interdisciplinary Handbook, 389-98. Berlin: Walter de Gruyter.

\section{Favell, Adrian}

1999 To belong or not to belong: The Postnational Question. - Andrew Geddes \& Adrian Favell (eds), The Politics of Belonging: Migrants and Minorities in Contemporary Europe, 209-27. Farnham/Surrey: Ashgate.

\section{Felski, Rita}

2008 Uses of Literature. Oxford: Blackwell.

\section{Hepokoski, Warren}

2002 The Laestadian Movement: Disputes and Divisions 1861-2000. Virginia: Culpeper. 


\section{Hintsala, Meri-Anna}

2012 Vanhoillislestadiolaisuus ja sukupuoli verkossa auto-netnografisesti tarkasteltuna. - Naistutkimus 25 (4), 29-38.

Hunt, Stephen \& Andrew Yip (eds)

2012 Ashgate Research Companion to Contemporary Religion and Sexuality. Farnham/Surrey: Ashgate.

\section{Hurtig, Johanna}

2013 Taivaan taimet. Uskonnollinen yhteisöllisyys ja väkivalta. Tampere: Vastapaino.

\section{Ihonen, Markku}

2001 Vaikenevat naiset. Keskustelua naisen paikasta 1800-luvun lestadiolaisuudessa. - Historiallinen Aikakauskirja 99 (3), 276-92.

\section{Kejonen, Eetu \& Meri-Anna Hintsala}

2013 Torjuttuna vai ymmärrettynä? Homoseksuaalisuuden kohtaaminen. Meri-Anna Hintsala \& Mauri Kinnunen (eds), Tuoreet oksat viinipuussa - Vanhoillislestadiolaisuus peilissä, 145-72. Helsinki: Kirjapaja.

\section{Kraus, Rachel}

2010 They Danced in the Bible: Identity Integration among Christian Women Who Belly Dance. - Sociology of Religion 71 (4), 457-82.

\section{Kutuniva, Mervi}

2007 Keskusteluja naiseudesta, vanhoillislestadiolaisesta uskosta ja uskonnosta. - Mervi Autti, Seija Keskitalo-Foley, Päivi Naskali \& Heidi Sinevaara-Niskanen (eds), Kuulumisia - Feministisiä tulkintoja naisten toimijuuksista, 17-36. Rovaniemi: LUP.

\section{Laestadian Lutheran Church (LLC)}

2016 Website of the Laestadian Lutheran Church. <http://www.llchurch.org>, accessed 2 February 2016.

\section{Linjakumpu, Aini}

2012 Haavoittunut yhteisö. Hoitokokoukset vanhoillislestadiolaisuudessa. Tampere: Vastapaino.

\section{Lohi, Seppo}

1997 Pohjolan kristillisyys. Lestadiolaisuuden leviäminen Suomessa 1870-1899. Oulu: SRK.

\section{McGuire, Meredith}

1997 Religion. The Social Context. Belmont: Wadsworth Publishing.

2007 Embodied Practices: Negotiation and resistance. - Nancy T. Ammerman (ed.), Everyday Religion. Observing Modern Religious Lives, 187-200. Oxford: Oxford University Press. 
2008 Lived Religion: Faith and Practice in Everyday Life. Oxford: Oxford University Press.

\section{Nissilä, Hanna-Leena}

2013 Kolonisoitu keho, yhteisöllinen minuus. - Matti Myllykoski \& Mikko Ketola (eds), Lestadiolaisuus tienhaarassa, 61-9. Helsinki: Vartija - Tolle Lege 2.

\section{Nykänen, Tapio}

2012 Kahden valtakunnan kansalaiset. Vanhoillislestadiolaisuuden poliittinen teologia. Rovaniemi: LUP.

2013 Jumalan valtakunnan kielioppi. Vanhoillislestadiolaisen vallan perusteet. - Tapio Nykänen \& Mika Luoma-aho (eds), Poliittinen lestadiolaisuus, 133-68. Helsinki: SKS.

\section{Pelkonen, Johanna}

2013 Nuoret naiset ja vanhoillislestadiolaisuuden murros. - Tapio Nykänen \& Mika Luoma-aho (eds), Poliittinen lestadiolaisuus, 171-205. Helsinki: SKS.

\section{Pink, Sarah}

2012 Situating Everyday Life: Practices and Places. London: Sage.

\section{Probyn, Elspeth}

1996 Outside Belongings. London: Routledge.

Puumala, Eeva \& Tarja Väyrynen \& Anitta Kynsilehto \& Samu Pehkonen 2011 Events of the Body Politic: A Nancian Reading of Asylum-seekers' Bodily Choreographies and Resistance. - Body E Society 17 (4): 83-104.

\section{Puumala, Eeva}

2012 Corporeal Conjunctures No-w-here. Failed Asylum Seekers and the Senses of the International. Tampere: Tampere University Press.

\section{Pylväinen, Hanna}

2012 We Sinners. New York: Henry Holt.

\section{Raittila, Pekka}

1982 Lestadiolaisuus Pohjois-Amerikassa vuoteen 1885. Helsinki: SKHS.

\section{Rauhala, Pauliina}

2013 Taivaslaulu. Helsinki: Gummerrus.

\section{Riis, Ole \& Linda Woodhead}

2010 A Sociology of Religious Emotion. Oxford: Oxford University Press.

\section{Rusu, Mihai}

2014 Literary fiction and social science. Two partially overlapping magisteria. - Journal of Comparative Research in Anthropology and Sociology 5 (2), 133-52. 


\section{Schilling, Chris}

2012 The Body and Social Theory, 3th edition. London: Sage.

\section{Snellman, Gerd}

2011 Sions döttrar. De laestadianska kvinnorna som traditionsförmedlare i norra svenska Österbotten åren 1927-2009. Turku: Åbo Akademi University Press.

Sjö, Sofia \& Andreas Häger

2015 Filmic constructions of the (religious) other: Laestadians, abnormality, and hegemony in contemporary scandinavian cinema. - Temenos 51 (1), 25-44.

Talonen, Jouko

2001 Lestadiolaisuuden hajaannukset. - Jouko Talonen \& Ilpo Harjutsalo (eds,) Iustitia 14, Suomen teologisen instituutin aikakauskirja, 11-30. Helsinki: STI.

Turner, Bryan

1984 Body and Society. Oxford: Blackwell.

\section{Utriainen, Terhi}

2006 Alaston ja puettu. Ruumiin ja uskonnon ääret. Tampere: Vastapaino

\section{Valkonen, Sanna}

2013 Lestadiolaisuuden jäljet saamelaisnaisten elämässä. - Tapio Nykänen \& Mika Luoma-aho (eds), Poliittinen lestadiolaisuus, 206-44. Helsinki: SKS.

\section{Wallenius-Korkalo, Sandra}

2013 Laestadian Girls in Forbidden Fruit: Representations of Gender, Place, and Agency. - Seija Keskitalo-Foley, Päivi Naskali \& Pälvi Rantala (eds), Northern Insights. Feminist Inquiries into Politics of Place, Knowledge and Agency, 174-200. Rovaniemi: LUP.

\section{Yip, Andrew \& Peter Nynäs}

2012 Re-framing the Intersection between Religion, Gender and Sexuality in Everyday Life. - Peter Nynäs \& Andrew Yip (eds), Religion Gender and Sexuality in Everyday Life: The Politics of Collective and Individual Identities, 1-16. Farnham/Surrey: Ashgate.

\section{Yuval-Davis, Nira}

2011 The Politics of Belonging. Intersectional Contestations. London: Sage. 